\title{
Recessional moraines in nearshore waters, northern Scotland
}

\author{
T. BRADWELL ${ }^{1,2} *$ \& M. S. STOKER ${ }^{1}$ \\ ${ }^{1}$ British Geological Survey, The Lyell Centre, Edinburgh, E14 4AP, UK \\ ${ }^{2}$ Biological \& Environmental Sciences, University of Stirling, FK9 4LA \\ *Corresponding author (e-mail:tom.bradwell @stir.ac.uk)
}

Suites of relatively small, similar-sized and regularly spaced sediment ridges are commonly found fronting the termini of present-day tidewater glaciers in fjords and marine embayments. These ice-flow transverse subaqueous moraine ridges, sometimes referred to as De Geer moraines, record the incremental retreat of the ice front grounding-line over time (De Geer 1889; Lindén \& Möller 2005). The distribution and pattern of wellpreserved transverse moraines in nearshore waters around Scotland has given valuable insight into the pattern, timing and style of retreat of the last British-Irish Ice Sheet (Bradwell et al. 2008a, b; Stoker et al. 2009).

\section{Description}

A suite of 40 to 50 seabed ridges occur in water depths typically from 30 to $80 \mathrm{~m}$ on shallow banks surrounding the Summer Isles, NW Scotland (Fig. 1). The ridges comprise two morphological groups: a more delicate set with smaller dimensions, and a more substantial set. Each ridge displays different planform morphology ranging from curvilinear to intricate (Fig. 1a,b). Occasionally ridges continue into water depths of $\sim 100 \mathrm{~m}$, but the ridges are notably absent in basins and bathymetric deeps $>100 \mathrm{~m}$ (Fig. 1a). The trend of the ridge crests is generally southsouthwest-north-northeast and individual ridges vary in length. The ridges can typically be traced horizontally for $3-5 \mathrm{~km}$, although shorter ridge fragments $(<500 \mathrm{~m}$ in length) also occur. The more delicate ridges are notably more discontinuous than the larger more substantial ridges. Most ridge crests are simple in planform, but a few ridges bifurcate or display multiple crestlines. In places, the more delicate ridges overprint the larger less well-defined ridges (Fig. 1b). The longest more substantial ridges cross-cut the seabed topography and traverse bathymetric ranges of $50 \mathrm{~m}$ or more.

The horizontal spacing between ridges varies but is generally between 100 to $1000 \mathrm{~m}$. Spacing between the more delicate ridges, around the western headlands, ranges from 100 to $500 \mathrm{~m}$ (Fig. 1b). Closer inshore between Tanera Mor and Carn nan Sgeir spacing between the larger ridges generally increases and can exceed $1000 \mathrm{~m}$, although ridge clustering occurs especially between topographic highs (Fig. 1a). Occasionally smaller more delicate ridges, with spacing of 50 to $300 \mathrm{~m}$, are found between the more substantial ridges (Fig 1a, b).

The seabed ridges vary in height and width. The more delicate ridges further offshore are smaller, being typically 2 to $4 \mathrm{~m}$ high and 30 to $50 \mathrm{~m}$ wide. The more substantial ridges closer to shore are generally 5 to $15 \mathrm{~m}$ high and approximately 80 to $200 \mathrm{~m}$ wide (Fig. 1a,b). The delicate ridges are generally symmetrical in cross section; the more substantial ridges tend to be asymmetric with a gentler slope to the southeast and a steeper slope to the northwest (Fig. 1c), although asymmetry is sometimes lacking.

A core taken from the flank of one of the seabed ridges recovered a massive, poorly sorted, matrix-supported diamicton with sandy-muddy matrix, and gravel and cobble grade clasts. Clasts were mostly of nonlocal lithology and some were faceted and striated (Fig. 1e). Dive photographs from ridge crests show large, lodged, sub-rounded to subangular boulders and cobbles set within a muddy matrix (Fig. 1d).

\section{Interpretation}

The seabed sediment ridges offshore of NW Scotland in the vicinity of the Summer Isles are interpreted to be subaqueous, ice-flow transverse moraines (some of which are De Geer moraines) formed at the grounded tidewater margin of an ice-sheet outlet glacier. Although no precise definition exists, the terms subaqueous moraine and De Geer moraine are sometimes used synonymously - with the latter being a subset of the former, based on geomorphological grounds. De Geer moraines are most commonly interpreted as marking former ice-front positions where sediment is dumped, squeezed or pushed up at grounded waterterminating glacier margins (Lindén \& Möller 2005; Todd et al. 2007). As in terrestrial settings, the process of subaqueous moraine formation is normally associated with brief stillstands or minor readvances of the ice front. Preserved suites of subaqueous moraines therefore record punctuated retreat during overall glacier recession. There is strong evidence that, in some cases at least, small closely spaced De Geer moraines form annually during winter push events at the grounding line (Boulton 1986; Ottesen \& Dowdeswell 2005).

The smaller seabed moraines $\sim 10 \mathrm{~km}$ NW of Tanera Mor exemplify De Geer moraines in nearshore waters around Scotland. With their delicate, superimposed, discontinuous form and small dimensions these features probably formed at the grounding line of a partly buoyant (lightly grounded) tidewater ice-sheet margin retreating and stabilising in shallower water (Stoker et al. 2009). Closer inshore, the more substantial, more laterally continuous subaqueous moraines with intricate planfoms and asymmetric cross-profiles suggest an oscillating highly crevassed tidewater ice margin strongly grounded on bathymetric/topographic highs, some of which probably acted as important pinning points during overall ice-front retreat.

Importantly, the details revealed by new high-resolution marinegeophysical surveys around the UK continue to direct geological sampling and prompt new geological mapping, assisting in the reconstruction and refinement of the pattern, timing and former style of British-Irish Ice Sheet decay.

\section{References}

BOULTON, G.S. 1986. Push moraines and glacier contact fans in marine and terrestrial environments. Sedimentology 33, 677-698.

BRADWELL, T., FABEL, D., STOKER, M.S., MATHERS, H., MCHARGUE, L. \& HOWE, J.A. 2008a. Ice caps existed throughout the Lateglacial Interstadial in northern Scotland. Journal of Quaternary Science 23, 401-407.

BRADWELL, T., STOKER, M.S., GOLLEDGE, N.R., WILSON, C.K., MERRITT, J.W., LONG, D., EVEREST, J.D., HESTVIK, O.B., STEVENSON, A.G., HUBBARD, A.L., FINLAYSON, A.G. \& MATHERS, H.E. 2008b. The northern sector of the last British Ice Sheet: Maximum extent and demise. Earth-Science Reviews 88, 207-226.

DE GEER, G.F. 1889. Ändmoräner I trakten mellan Spånga och Sundbyberg. Geologiska Föreningens i Stockholm Förhandlingar 11, 395-397.

LINDÉN, M. \& MÖLLER, P. 2005. Marginal formation of De Geer moraines and their implication on the dynamics of grounding-line recession. Journal of Quaternary Science 20, 113-133.

OTTESEN, D. \& DOWDESWELL, J.A. 2006. Assemblages of submarine landforms produced by tidewater glaciers in Svalbard. Journal of Geophysical Research 111, F01016.

STOKER, M.S., BRADWELL, T., HOWE, J.A., WILKINSON, I.P. \& McINTYRE, K. 2009. Lateglacial ice cap dynamics in NW Scotland: evidence from the fjords of the Summer Isles region. Quaternary Science Reviews 28, 3161-84.

TODD, B.J., VALENTINE, P.C., LONGVA, O. \& SHAW, J. 2007. Glacial landforms on German Bank, Scotian Shelf: evidence for Late Wisconsinan icesheet dynamics and implications for the formation of De Geer moraines. Boreas 36, 148-169. 


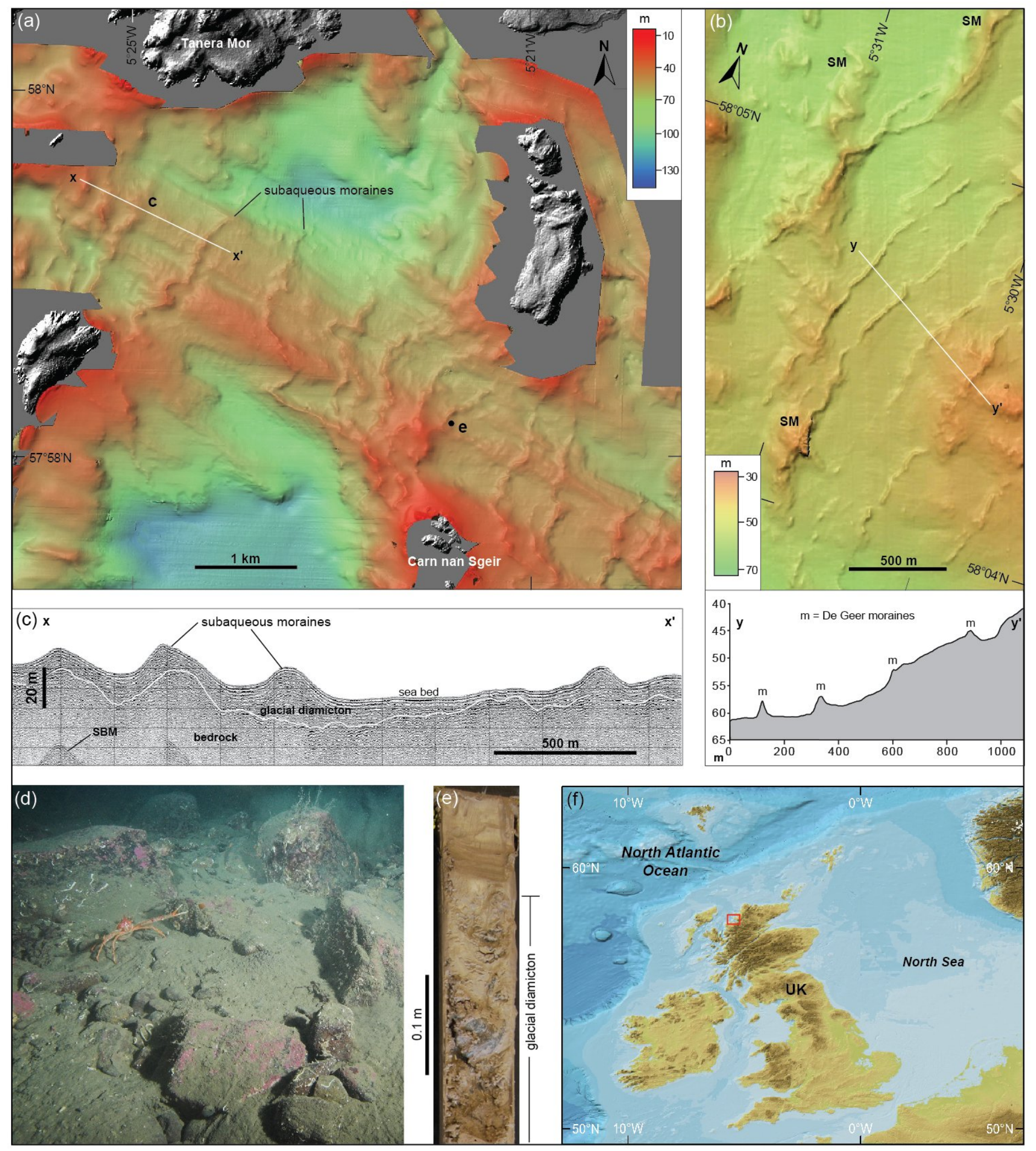




\section{T. BRADWELL, M.S. STOKER}

\section{Figure caption}

Fig. 1. Multibeam bathymetry, geophysical profiles and geological samples from subaqueous moraines in the Summer Isles region, NW Scotland, UK. (a) Multibeam bathymetric image showing suite of seabed moraines between Tanera Mor and Carn nan Sgeir. Note the intricate planform morphology, and the absence of moraines in deeper-water basins. Multibeam acquisition system Geoswath. Frequency $125 \mathrm{kHz}$. Grid-cell size $5 \mathrm{~m}$. (b) Multibeam bathymetric image of seabed moraines $\sim 10 \mathrm{~km}$ NW of Tanera Mor. Same acquisition system. Note the small delicate De Geer moraines (m) overprinting the larger older set of subaqueous moraines (SM). Location of seabed morphological profile (lower panel) shown by line y-y'. (c) British Geological Survey seismic reflection (boomer) profile of seabed moraines between Tanera Mor and Carn nan Sgeir. Acquisition system Applied Acoustics surfacetow boomer. Frequency $12 \mathrm{kHz}$. Note the asymmetric cross profile of moraines. Bedrock/diamicton contact mapped where acoustically resolvable. SBM - seabed multiple. (d) Underwater photograph of subaqueous moraine in Summer Isles region at $35 \mathrm{~m}$ water depth showing large boulders on ridge crest. Squat lobster with outstretched claws ca. $0.5 \mathrm{~m}$ wide. (Image: R. Shucksmith). (e) Glacial diamicton recovered in BGS core 57-06/262 from flank of subaqueous moraine ridge $\left[57.968^{\circ} \mathrm{N}, 05.357^{\circ} \mathrm{W}\right]$. (f) Location of study area (red box; map from IBCAO v.3.0). 